\title{
FOOD WASTE MANAGEMENT FRAMEWORK TO SUPPORT SUSTAINABLE AGRICULTURE IN PAGAR ALAM CITY OF SOUTH SUMATERA
}

\section{KERANGKA PENGELOLAAN SAMPAH MAKANAN UNTUK MENDUKUNG PERTANIAN BERKELANJUTAN DI KOTA PAGAR ALAM SUMATERA SELATAN}

\author{
Dian Novriadhy $^{1}$ and Oktaf Juairiyah ${ }^{2}$ \\ 12 Badan Penelitian dan Pengembangan Daerah Provinsi Sumatera Selatan \\ E-mail: dian.novriadhy@gmail.com
}

Naskah Masuk: 19-07-2018

Naskah Diterima: 14-12-2018

Naskah Disetujui: 15-12-2018

\begin{abstract}
ABSTRAK
Mengembalikan sampah makanan (SM) sebagai kompos ke lahan pertanian dianggap sebagai salah satu opsi terbaik untuk memastikan keberlanjutan pertanian bagi kota-kota yang bergantung pada sektor pertanian sebagai tulang punggung dari modal pembangunan mereka seperti Kota Pagar Alam. Sementara pengomposan SM mudah dilakukan dalam skala kecil, membuat kompos dari SM di tingkat kota merupakan tugas yang memberatkan yang berarti perlu pengelolaan sampah yang tepat. Oleh karena itu, penelitian ini bertujuan untuk mengembangkan kerangka kerja manajemen SM untuk Kota Pagar Alam berdasarkan metodologi Life Cycle Assessment. Variabel yang dimasukkan dalam kerangka adalah struktur usia rumah tangga, kebiasaan makan, pengeluaran makanan per kapita, penghasilan kepala rumah tangga, praktik belanja, perilaku pemisahan sampah dan sikap pada barang bekas. Temuan menunjukkan timbulan SM dipengaruhi oleh struktur usia rumah tangga serta pengeluaran makanan. Jumlah anggota rumah tangga di bawah usia lima tahun memiliki pengaruh lebih besar terhadap timbulan SM (Exp $\beta=$ $5,04)$ daripada pengeluaran makanan per kapita $(4,37)$ atau jumlah anggota rumah tangga yang berusia lima tahun atau lebih (2,16). Alasan mengapa rumah tangga tidak melakukan pemilahan sampah adalah terlalu malas, memiliki kesenjangan pengetahuan dan kurangnya fasilitas. Temuan menyarankan otoritas lokal untuk mengintegrasikan pengumpul sampah informal ke dalam sistem pengelolaan sampah dan menciptakan permintaan pasar kompos untuk mengatasi hambatan sosial yang ada. Studi ini menyimpulkan bahwa dimasukkannya struktur usia rumah tangga dan perubahan perilaku masyarakat dalam kerangka kerja manajemen SM sangat penting.
\end{abstract}

Kata kunci: pengelolaan sampah, perilaku membuang sampah, sampah rumah tangga, timbulan sampah makanan

\begin{abstract}
Returning the food waste ( $\mathrm{FW}$ ) as compost to farmlands is considered as one of the best options to ensure the agricultural sustainability for cities that rely on the agricultural sector as the backbone of their development capital such Pagar Alam City. While composting FW is easy on small-scale, making compost from FW at a city level is a burdensome task which means its need appropriate waste management. Therefore, the study aimed to develop an FW management framework for Pagar Alam City based on Life Cycle Assessment methodology. Variables included in the framework were the household's age structure, eating habits, food expenditures per capita, household's head income, shopping practices, waste separation behavior and attitude on used goods. The findings showed the FW generation was influenced by household age structure as well as food expenditures. The number of under-five-year-inhouseholds had more influence on FW generation $(\operatorname{Exp} \beta=5.04)$ rather than the food expenditures per capita (4.37) or the number of household members aged five years or over (2.16). The reasons why households did not do a waste separation were being too lazy, having a knowledge gap and lack of facilities. The findings suggested the local authority to integrate informal waste collectors into a waste management system and created such compost market demand to overcome existing societal barriers. The study concluded that the inclusion of the household age structure and community behavioral changes issues in the FW management framework were essential.
\end{abstract}

Keywords: food waste generation, household's waste, waste disposal behaviour, waste management 


\section{INTRODUCTION}

Rapid urbanization causes land conversion of many agricultural sites into settlements. Consequently, the distance of the food source location to urban center become farther away. The possibility of the food waste not going back to agricultural sites is widely open. For instance, the food for Palembang's citizens is supplied from surrounding areas such as Ogan Ilir District or Banyuasin District, but the food waste remained in Palembang (treated in the landfill). As a result, the soil's nutrient cycle has interrupted that caused degradation of soil quality and led to an increase in synthetic fertilizer use. The more synthetic fertilizer use meant the more damage to the environment. Similar situation on what Marxian called as metabolic rift (Foster, 1999). The agricultural sustainability slowly diminished and in the long run it will hamper the growth of cities that rely on the agricultural sector as the backbone of their development capital such Pagar Alam City. Therefore, returning the food waste as compost to farmlands is considered as one of the best options to ensure the agricultural sustainability.

While composting food waste is easy on small-scale, making compost from food waste at a city level is a burdensome task which means its need appropriate waste management. Research related to waste management in Indonesia had been done before in various situations and conditions. Some of them had investigated the potential of food waste as renewable resources (Kerstens et al., 2016), to find the most efficient way in waste handling (MacRae \& Rodic, 2015), to explain human behavior influencing in waste separation and handling (Permana, Towolioe, Aziz, \& Ho, 2015) and many others. But as far as the author's knowledge, a study investigating food waste management as an activity conducted systematically through continuous ways covering the reduction and waste handling was rare.

In the attempt to meet the regulation requirement and to accommodate the Pagar Alam City's authority needs, the waste management model would be built in a systematical approach using a life cycle assessment (LCA) methodology. The LCA use was common in a waste management model development. Nevertheless, none of 222 articles of a solid waste management system that used the LCA methodology took the identification of the context situation as proposed in the guideline literature 
(Laurent et al., 2014). This finding had attracted author to apply LCA's perspective in a waste management model development with consideration of the local characteristics and the local context situation of Pagar Alam City.

Three prominent issues should be considered in the model development. First, the top out of three of economic sectors that mostly contributed to regional GDP showed the difference of the Pagar Alam City from other municipalities in South Sumatera Province. It was clear that the Pagar Alam City highly depended on agricultural sector which meant the local authorities should prioritize activities that made agriculture sustainable. In our context, converting food waste to compost became a rational choice. Second, the study had to consider a technical aspect of waste collection in settlements near a water body since the proportion of household that disposed a waste into a river was substantially large. Third, the model had to reveal a connection between waste separation habits and composting activities. Therefore, the study aimed to develop food waste management model for Pagar Alam City to support the Low External Input Sustainable Agriculture (LEISA) spesifically 1) to obtain food waste generation model and 2) to explain suitable framework for food waste handling.

\section{METHODOLOGY}

\section{Materials}

The study used two survey datasets provided by The Statistics Indonesia i.e. the Social Economic National Survey (Survei Sosial Ekonomi Nasional/ SUSENAS) of 2013 and the Survey of Environmental Caring Behavior (Survei Perilaku Peduli Lingkungan Hidup/ SPPLH) of 2013, and other relevant institutional data. The two surveys are described in the following:

(i) The SUSENAS of 2013 was held using the stratified-proportionally random sampling technique and could be used for estimation as far as a municipality level. The SUSENAS of 2013 datasets had recorded the amount of a household's waste generation as well as socio-economic and demographic characteristics. The number of the sampling units for Pagar Alam City was 116 units.

(ii) The SPPLH of 2013 used the stratified random sampling technique and had some limitation for estimation of a certain variable 
at an individual level. The SPPLH of 2013 datasets had recorded solid waste management variables at a household level. The number of the sampling units for Pagar Alam City was 113 units.

\section{Methods}

Only household food waste was analyzed in the model. Therefore, the food waste had been generated from the hospitality services and fresh food markets were excluded from the model. The functional unit of the model was the food waste generated by households in the Pagar Alam City of South Sumatera for one year for the baseline year 2013, whereas the reference flow of the model was the number of bags of the solid waste generated by one unit of household daily. The Statistics Indonesia did not make an explanation on the conversion unit of a bag of the solid waste. Thus, the study assumed that one bag of the solid waste was equal to one kilogram of the solid waste containing the food waste at least $50 \%(\mathrm{w} / \mathrm{w})$.

\section{Food Waste Generation Analysis}

The factors that had affected the food waste generation (FWG) already known (Edjabou, Petersen, Scheutz, \& Astrup, 2016; Chalak, Abou-Daher, Chaaban, \& Abiad, 2016; Parizeau, von Massow, \&
Martin, 2015) which a few among others were the number of household members, the household consumption pattern, the household income, and their expenditure. The previous findings had shown that the rate of household's waste generation per capita would decrease if the household size increased which meant the households age structure had an influence on the waste generation (Bandara, Hettiaratchi, Wirasinghe, \& Pilapiiya, 2007).

Two FWG models had been developed based on Binary Logistic Regression approach and been compared to get a better understanding on the influencing factors of a food waste generation. In Model 1 the total number of a household member was used as a predictor just like common FWG model had developed elsewhere whereas for Model 2 the number of under-five and the number of the rest of household member were used instead of the total number of a household member. The predictors' replacement in FWG Model was used to obtain a better understanding which one gave more realistic prediction model since Pagar Alam City considered as one of a city that has relatively high fertility. 
Model 1:

$$
\begin{gathered}
\log \frac{P}{1-P}=\alpha_{1}+\beta_{1} \cdot X_{1}+\beta_{2} \cdot X_{2} \\
+\beta_{3} \cdot X_{3}
\end{gathered}
$$

Model 2:

$$
\begin{gathered}
\log \frac{P}{1-P}=\alpha_{2}+\beta_{1} \cdot X_{1}+\beta_{2} \cdot X_{2}+\beta_{4} \cdot X_{4} \\
+\beta_{5} \cdot X_{5}
\end{gathered}
$$

note:

P : Probability of food waste more than 1 bag (daily disposal)

$\alpha_{1}, \alpha_{2} \quad$ : intercept

$\beta_{1} \ldots \beta_{5}:$ regression coefficient

$\mathrm{X}_{1} \quad$ : Average daily consumption of fruits and vegetables per capita

$\mathrm{X}_{2} \quad$ : Log of food expenditure per capita

$\mathrm{X}_{3} \quad \cdot \quad$ Total number of household

$\mathrm{X}_{4} \quad$ : Number of under-five years old of household's member

$\mathrm{X}_{5} \quad$ : Number of five years old and over of household's member

\section{Food Waste Handling Analysis}

The effectiveness of waste management depended on the knowledge of the waste composition and the pretreatment. This statement had an implication that knowing household habits on waste disposal practice, waste handling service coverage, and supporting facilities were essential in a waste management model development (Sukholthaman \& Sharp, 2016). Therefore, the study used variables of a shopping practice, a waste separation practice, and household's attitude on used goods to develop a modeling framework of food waste handling. All variables had been taken from the SPPLH of 2013. The framework was developed based on a qualitative approach with the following steps:

(i) identifying waste composition and household's waste disposal method

(ii) identifying an obstacle factor for households to do a waste separation

(iii) identifying the existing social capitals in communities to strengthen waste management program implementation

(iv) identifying a causal relationship might exist between the obstacle factors and the social capitals

\section{RESULTS AND DISCUSSION}

\section{Food Waste Generation Model}

Model 1 showed an agreement on the result of many previous studies that the number of household members was a strong indicator for food waste generation (Edjabou et al., 2016) whereas the fresh fruits and vegetables daily consumption per capita and the food expenditures per capita had proved statistically insignificant. The improvement of Model 1 was achieved by substitution of the variable of the total number of household members by the number of under-five and the household members aged five years old and over. 
As showed in Model 2, the food expenditures per capita had a significant influence on the food waste generation whereas the fresh fruits and vegetables daily consumption per capita were still found statistically insignificant. The factors that had influenced the food waste generation from the strongest to the weak were the number of under-five years old of household members, food expenditures per capita, and the number of five years old and over of household members (Table 1).

The findings showed that the household's age structure was a more appropriate variable to be included in the household waste generation model rather than the total number of households member for Pagar Alam City which had a opulation with a pyramid model that characterizes a relatively high population growth.

Table 1. Parameter estimates of the food waste generation model for the Pagar Alam City (based on Binary Logistics Regression)

\begin{tabular}{|c|c|c|c|c|c|c|}
\hline \multirow{2}{*}{ Variables } & \multicolumn{3}{|c|}{ Model 1} & \multicolumn{3}{|c|}{ Model 2} \\
\hline & $\beta$ & S.E. & $\exp (\beta)$ & $\beta$ & S.E. & $\exp (\beta)$ \\
\hline $\begin{array}{l}\text { Average daily consumption of } \\
\text { fruits and vegetables per capita }\end{array}$ & -.10 & .21 & .90 & -.12 & .21 & .89 \\
\hline $\begin{array}{l}\text { Log of food expenditure per } \\
\text { capita }\end{array}$ & 1.25 & .79 & 3.48 & $1.47 *$ & .80 & 4.37 \\
\hline $\begin{array}{l}\text { Total number of household } \\
\text { member }\end{array}$ & $.84 * *$ & .35 & 2.31 & - & & - \\
\hline $\begin{array}{l}\text { Number of under-five years old } \\
\text { of household's member }\end{array}$ & - & & - & $1.62 * *$ & .70 & 5.04 \\
\hline $\begin{array}{l}\text { Number of five-years-old-and- } \\
\text { over of household's member }\end{array}$ & - & & - & $.77 * *$ & .35 & 2.16 \\
\hline
\end{tabular}

Based on Model 2, an increased of food expenditure per capita would increase food waste 3.03 times greater than the bases at beginning. But, the magnitude of food waste increases getting less as the food expenditure per capita grew further. An increase of an under-five child predicted to increase food waste 5.04 times greater than the bases while an increase of a five-years-old-and-over of household's member would increase 2.16 times greater. In other word, an underfive child generated food waste 2.88 times greater than others household member.

Children under-five were commonly found not having regular eating habits. Empirically, a person who was responsible for taking care the children under-five frequently had let the underfive to determine own food preferences in which for the too picky children would 
tend to result in a food waste. For that reasons, the local government needed to educate the community about nutrition facts, introduced functional foods, and skill in the food serving. Increasing parent awareness on the potential impact of feeding practices to children's food acceptance was an important step to improve child eating habits (Kaar, Shapiro, Fell, \& Johnson, 2016). These food education and training also had a positive impact that would promote healthy eating habits and improve the quality of young children's diets (Jarman et al., 2015).

\section{The Modeling Framework of Food} Waste Handling

Municipal solid waste (MSW) of Pagar Alam City comprised over $50 \%$ of food waste which meant a good resource indicator for the compost was even better if other organic compounds were taken into account (Figure 1). But, the problem with MSW use for the compost resources perhaps came from the household's waste disposal behavior.

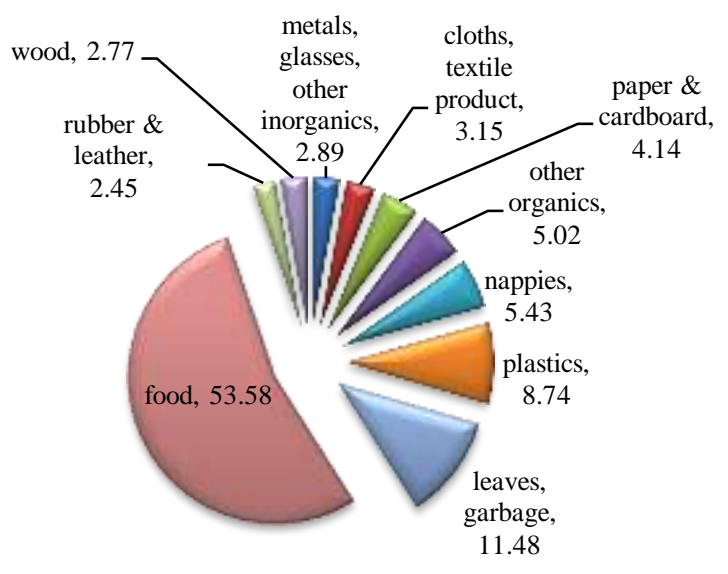

source: JICA South Sumatera (2013)

Figure 1. Municipal solid waste compositions of the Pagar Alam City as taken in the Landfilled site

Table 2. Distribution of household regarded waste disposal method in the Pagar Alam City 2013

\begin{tabular}{|c|c|c|c|}
\hline \multirow{2}{*}{ Waste disposal method } & \multicolumn{2}{|c|}{ Responses } & \multirow{2}{*}{$\begin{array}{l}\text { Proportion of Household } \\
(\%)^{*}\end{array}$} \\
\hline & $\mathbf{N}$ & $\%$ & \\
\hline Disposed to the temp./final disposal site & 55 & 33.3 & 48.7 \\
\hline Burned & 52 & 31.5 & 46.0 \\
\hline Disposed into the water body & 18 & 10.9 & 15.9 \\
\hline Sold to waste collectors & 18 & 10.9 & 15.9 \\
\hline Disposed carelessly & 12 & 7.3 & 10.6 \\
\hline Feed to livestock & 4 & 2.4 & 3.5 \\
\hline Composted & 3 & 1.8 & 2.7 \\
\hline Landfilled & 3 & 1.8 & 2.7 \\
\hline Total & 165 & 100.0 & \\
\hline
\end{tabular}

The study revealed that only onehad sorted out their waste was small third of the household that frequently (maximum at $12.4 \%$ ) which meant the used waste handling facility. Households food waste collected in mixed forms. The 
proportion of the household that sold their waste to waste traders was quite large $(15.9 \%)$, but only $.9 \%$ of the households regularly used that way. The waste disposal methods most frequently used were 1) disposing to the disposal site, 2) burning, and 3) disposing of into the water body (Table 2). Several factors had been found as an obstacle for households to do a waste separation. Sorting out a waste was unprofitable (8.1\%), not having a waste separation facilities (9.1\%), not knowing a waste that should be separated (21.2\%), and the laziness $(61.6 \%)$ had dominated the household answer to the question of why not doing a waste separation.

The findings revealed two broad aspects that should be concerned in a modeling framework development of food waste handling i.e. a social aspect and a technical aspect. The recent study had emphasized the existence of interconnection of the social aspect and the technical aspect in shaping an individual or society behavior (Morris, Marzano, Dandy, \& O’Brien, 2012).
Previous studies revealed that a waste separation was a key to every waste management system regardless the type of waste treatment had been implemented. Therefore, the modeling framework of food waste handling should focus on creating an enabling environment for food waste separation (Figure 2). In general, the local government had to change the community behavior to achieve a better waste management. The obstacle factors found were a common shared problem faced by the local government in Indonesia. The local government could implement a social engineering program that targeted to change community behavior to overcome societal barriers that existed. The local government could adopt the doorstepping approach that effectively increased the proportion of household that did do a food waste separation (Dai et al., 2015). Pagar Alam City had basic social capitals to implement the doorstepping approach such as the program of empowerment and family welfare, the social gathering, and community service. 


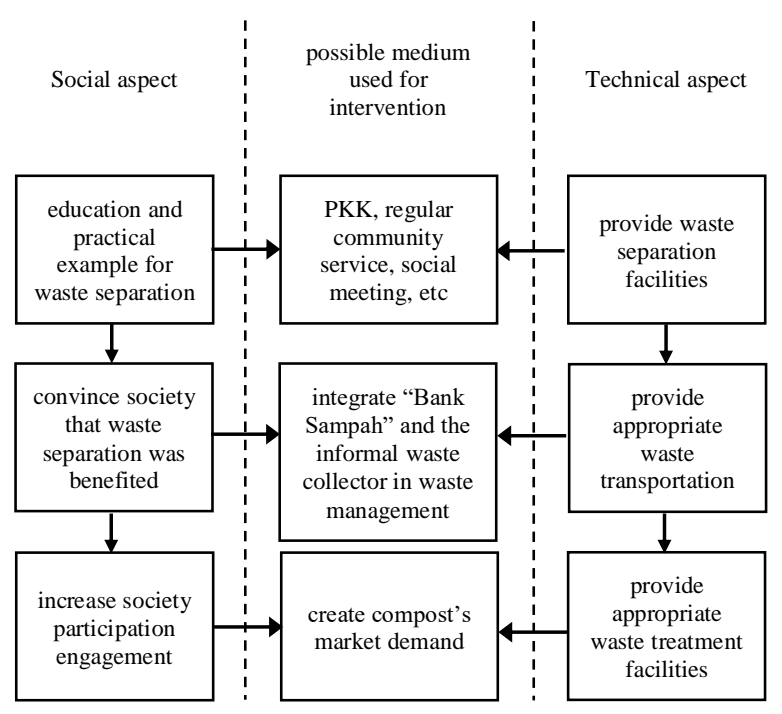

Figure 2. Modeling framework of food waste handling and possible medium used for its implementation

The local government could capitalize the existing social capital to educate and to change community behavior by providing a direct practical example on how to manage a waste properly. The effectiveness of the doorstepping approach also highly correlated to the local government ability in providing waste separation facilities. The local government should be able to convince the community that waste separation activity gave benefits to individuals, to communities, and to an environment (Nguyen, Zhu, \& Le, 2015). Claims of such benefits should be made by a third party to gain a more trust from the public. The previous study had documented that the differences in people's motivation had contributed to the differences in levels of food waste separation efficiency (Boonrod, Towprayoon, Bonnet, \& Tripetchkul, 2015). The local government had to set up a waste transportation mechanism to ensure the waste that had been sorted out would not mix back when transported to final waste treatment facilities.

The local government was also favored of integrating informal waste collectors and "bank sampah" (a type of organization that allows people to save a waste then convert to a cash later) into the waste management system (Fei, Qu, Wen, Xue, \& Zhang, 2016). The local government could create market demand on compost rather than gave an economic incentive to counter a household perception that did do a waste separation was unprofitable. Economics incentives at a certain case proved failed to encourage households to separate their waste (Owusu, Adjei-Addo, \& Sundberg, 2013). The compost market would complement the market of recyclable- 
reusable materials already existed. In this way, society would think that the food waste was not just purely a waste but had an economic value. The mindset changing would increase household's participation in waste separation activity voluntarily. Bangladesh's Mirpur experiences had proved that market demand for the compost had increased public participation in waste management, created a job opportunity for the poor, and produced a value-added product for agriculture needs (Zurbrügg, Drescher, Rytz, Sinha, \& Enayetullah, 2005). Although was not easy, the local government could establish a partnership with state-owned enterprises in the creation of compost market through the Corporate Social Responsibility (CSR) program. The CSR should be designed not just to give a donation but more tended to build community environmental awareness via household income generation via sustained food waste handling activities.

Most of the food waste in the Pagar Alam City was treated as landfilled and incinerated in which none of those treatments could fully recover essential soil's nutrients such as nitrogen $(\mathrm{N})$ and phosphorus $(\mathrm{P})$. On the others side, a food waste compost application offered such benefits on a recovery of $\mathrm{N}$ and $\mathrm{P}$ although it had to consider the side effect of an accumulation of heavy metal and toxic substance in agricultural site. The MSW compost application indeed increased soil quality (Zabaleta \& Rodic, 2015) but the MSW compost capability to reduce deficiency of $\mathrm{N}$ and $\mathrm{P}$ depended on an initial food waste composition (Lederer, Karungi, \& Ogwang, 2015). The MSW compost application in Tea Plantation increased plant biomass production and was environmentally safe in respect to Chromium (Cr) (Karak et al., 2014). But, another study had found that the MSW compost application accumulated Aluminum ( $\mathrm{Al})$ in a different part of Tea though considered still on the safe level in the infused part (Karak et al., 2015).

\section{CONCLUSIONS}

The study concluded that using the household's age structure would give better food waste generation prediction rather than the total number of households member for Pagar Alam City. The factors that had influenced the food waste generation from the strongest to the weak were the number of under-five years old of household members, food expenditures per capita, and the number of five years old and over of household 
members.

\section{RECOMMENDATION}

The modeling framework of food waste handling should focus on creating an enabling environment for food waste separation with emphasized on the existence of interconnection of the social aspect and the technical aspect in shaping an individual or society behavior.

Nevertheless, precautions should be made followed by some study

\section{REFERENCES}

Bandara, N. J. G. J., Hettiaratchi, J. P. A., Wirasinghe, S. C., \& Pilapiiya, S. (2007). Relation of waste generation and composition to socio-economic factors: a case study. Environmental Monitoring and Assessment, 135(13), 31-39.

http://doi.org/10.1007/s10661-0079705-3

Boonrod, K., Towprayoon, S., Bonnet, S., \& Tripetchkul, S. (2015). Enhancing organic waste separation at the source behavior: A case study of the application of motivation mechanisms in communities in Thailand. Resources, Conservation and Recycling, 95, 77-90. http://doi.org/10.1016/j.resconrec.20 14.12.002

Chalak, A., Abou-Daher, C., Chaaban, J., \& Abiad, M. G. (2016). The global economic and regulatory determinants of household food waste generation: A cross-country analysis. Waste Management (Vol. 48).

http://doi.org/10.1016/j.wasman.201 5.11 .040

Dai, Y. C., Gordon, M. P. R., Ye, J. Y., Xu, D. Y., Lin, Z. Y., Robinson, N. K. L., ... Harder, M. K. (2015). limitations. The sample unit of the SUSENAS and the SPPLH were different. Therefore, the link between the household's waste generation and the household's waste disposal behavior had not been explored yet. The LCA methodology was known as an iterative process, and consequently the study findings should be considered as a preliminary result.

Why doorstepping can increase household waste recycling. Resources, Conservation and Recycling, 102, 9-19. http://doi.org/10.1016/j.resconrec.20 15.06.004

Edjabou, M. E., Petersen, C., Scheutz, C., \& Astrup, T. F. (2016). Food waste from Danish households: Generation and composition. Waste

Management, 52, 256-268. http://doi.org/10.1016/j.wasman.201 6.03.032

Fei, F., Qu, L., Wen, Z., Xue, Y., \& Zhang, H. (2016). How to integrate the informal recycling system into municipal solid waste management in developing countries: Based on a China's case in Suzhou urban area. Resources, Conservation and Recycling, 110, 74-86. http://doi.org/10.1016/j.resconrec.20 16.03.019

Foster, J. B. (1999). Marx's Theory of Metabolic Rift: Classical Foundations for Environmental Sociology. American Journal of Sociology, 105(2), 366-405. http://doi.org/10.1086/210315 Jarman, M., Ogden, J., Inskip, H., Lawrence, W., Baird, J., Cooper, C., ... Barker, M. (2015). How do 
mothers manage their preschool children's eating habits and does this change as children grow older?

A longitudinal analysis. Appetite, 95, 466-474.

http://doi.org/10.1016/j.appet.2015.0 8.008

JICA South Sumatera (Ed.). (2013). PEP RAD-GRK Provinsi Sumatera Selatan Sektor Pengelolaan Limbah (Domestik). Palembang: Japan International Cooperation Agency.

Kaar, J. L., Shapiro, A. L. B., Fell, D. M., \& Johnson, S. L. (2016). Parental feeding practices, food neophobia, and child food preferences: What combination of factors results in children eating a variety of foods? Food Quality and Preference, 50, 57-64.

http://doi.org/10.1016/j.foodqual.20 16.01.006

Karak, T., Paul, R. K., Sonar, I., Sanyal, S., Ahmed, K. Z., Boruah, R. K., ... Dutta, A. K. (2014). Chromium in soil and tea (Camellia sinensis L.) infusion: Does soil amendment with municipal solid waste compost make sense? Food Research International, 64, 114-124. http://doi.org/10.1016/j.foodres.201 4.06.006

Karak, T., Sonar, I., Paul, R. K., Frankowski, M., Boruah, R. K., Dutta, A. K., \& Das, D. K. (2015). Aluminium dynamics from soil to tea plant (Camellia sinensis L.): is it enhanced by municipal solid waste compost application? Chemosphere, 119, 917-26.

http://doi.org/10.1016/j.chemospher e.2014.08.067

Kerstens, S. M., Priyanka, A., van Dijk, K. C., De Ruijter, F. J., Leusbrock, I., \& Zeeman, G. (2016). Potential demand for recoverable resources from Indonesian wastewater and solid waste. Resources,
Conservation and Recycling, 110, 16-29.

http://doi.org/10.1016/j.resconrec.20 16.03.002

Laurent, A., Clavreul, J., Bernstad, A., Bakas, I., Niero, M., Gentil, E., ... Hauschild, M. Z. (2014). Review of LCA studies of solid waste management systems - Part II: Methodological guidance for a better practice. Waste Management, 34(3), 589-606.

http://doi.org/10.1016/j.wasman.201 3.12.004

Lederer, J., Karungi, J., \& Ogwang, F. (2015). The potential of wastes to improve nutrient levels in agricultural soils: A material flow analysis case study from Busia District, Uganda. Agriculture, Ecosystems \& Environment, 207, 26-39.

http://doi.org/10.1016/j.agee.2015.0 3.024

MacRae, G., \& Rodic, L. (2015). The weak link in waste management in tropical Asia? Solid waste collection in Bali. Habitat International, 50, 310-316.

http://doi.org/10.1016/j.habitatint.20 15.09.002

Morris, J., Marzano, M., Dandy, N., \& O'Brien, L. (2012). Theories and models of behaviour and behaviour change. Forestry, sustainable behaviours and behaviour change: Theories. Retrieved from http://www.forestry.gov.uk/pdf/beha viour_review_theory.pdf/\$FILE/beh aviour_review_theory.pdf

Nguyen, T. T. P., Zhu, D., \& Le, N. P. (2015). Factors influencing waste separation intention of residential households in a developing country: Evidence from Hanoi, Vietnam. Habitat International, 48, 169-176. http://doi.org/10.1016/j.habitatint.20 15.03.013 
Owusu, V., Adjei-Addo, E., \& Sundberg, C. (2013). Do economic incentives affect attitudes to solid waste source separation? Evidence from Ghana. Resources, Conservation and Recycling, 78, 115-123. http://doi.org/10.1016/j.resconrec.20 13.07.002

Parizeau, K., von Massow, M., \& Martin, R. (2015). Household-level dynamics of food waste production and related beliefs, attitudes, and behaviours in Guelph, Ontario. Waste Management, 35, 207-217. http://doi.org/10.1016/j.wasman.201 4.09.019

Permana, A. S., Towolioe, S., Aziz, N. A., \& Ho, C. S. (2015). Sustainable solid waste management practices and perceived cleanliness in a low income city. Habitat International, 49, 197-205.

http://doi.org/10.1016/j.habitatint.20 15.05.028

Sukholthaman, P., \& Sharp, A. (2016). A system dynamics model to evaluate effects of source separation of municipal solid waste management: A case of Bangkok, Thailand. Waste Management, 52, 50-61. http://doi.org/10.1016/j.wasman.201 6.03.026

Zabaleta, I., \& Rodic, L. (2015).

Recovery of essential nutrients from municipal solid waste--Impact of waste management infrastructure and governance aspects. Waste Management (New York, N.Y.), 44, 178-87.

http://doi.org/10.1016/j.wasman.201 5.07.033

Zurbrügg, C., Drescher, S., Rytz, I., Sinha, A. H. M. M., \& Enayetullah, I. (2005). Decentralised composting in Bangladesh, a win-win situation for all stakeholders. Resources, Conservation and Recycling, 43(3), 281-292. http://doi.org/10.1016/j.resconrec.20 04.06.005 